\title{
NATIONAL WATER-QUALITY ASSESSMENT PROGRAM Great Salt Lake Basins study unit
}

\section{Water-quality issues in the Great Salt Lake Basins NAWQA study unit}

The Great Salt Lake Basins NAWQA study will increase the scientific understanding of the factors that influence surface- and ground-water quality. This information will benefit water-resources managers that need, but often lack, the data required to implement effective water-quality management actions and evaluate longterm changes in water quality.

Point and nonpoint sources of pollution, including leachates from mining waste rock and mill tailings, urban runoff, industrial activities, agriculture, and wastewater treatment plants, have affected the ground-and surface-water resources in the Great Salt Lake Basins study unit.

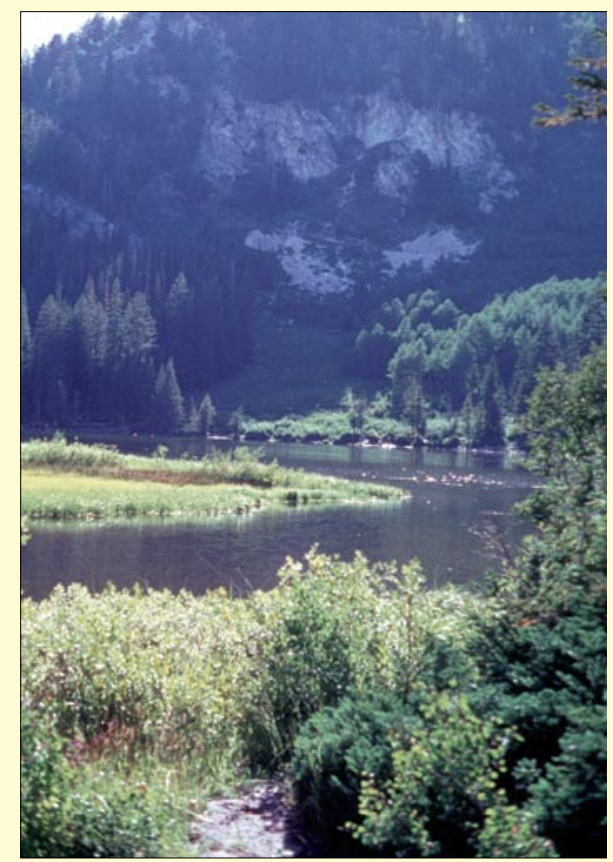

Headwater wetlands.

On the basis of previous and ongoing studies and discussions at liaison committee meetings, the following water-quality issues have been identified:

\section{What is the National Water-Quality Assessment program?}

In 1991, the U.S. Geological Survey (USGS) began implementing a full-scale National Water-Quality Assessment (NAWQA) program.

The long-term goals of the NAWQA program are to describe the status and trends in the quality of a large, representative part of the Nation's surface- and ground-water resources and to provide a sound, scientific understanding of the primary natural and human factors that affect the quality of these resources. In meeting these goals, the program will produce a wealth of water-quality information that will be useful to policy makers and managers at Federal, State, and local levels.

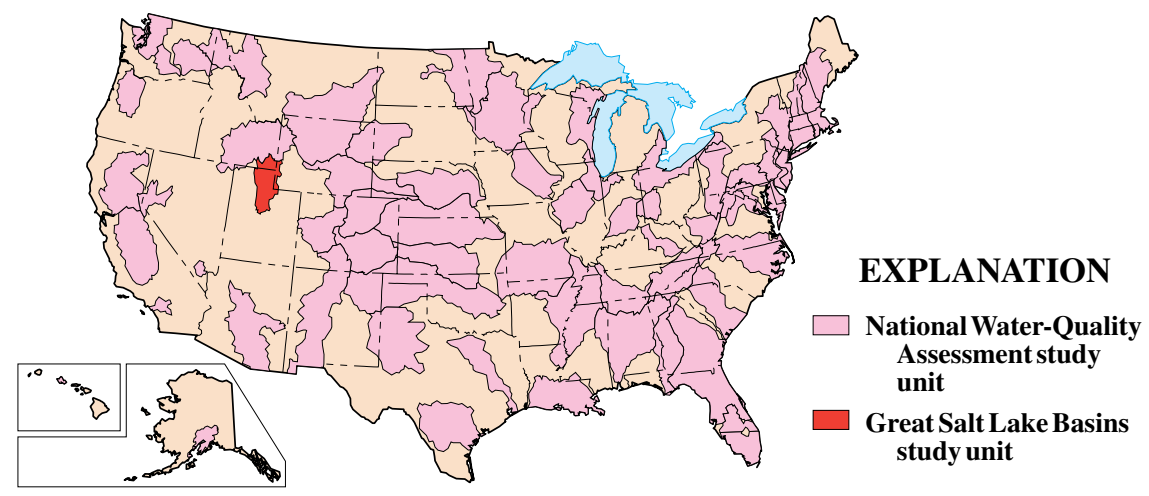

The principal building block of the program is the study unit. Each study unit is composed of important river and aquifer systems that represent the diverse geography, water resources, and land and water uses of the Nation. National-level assessment activities will be based on the study units, and water-quality information at different scales can be integrated. Implementation of the NAWQA program for the Great Salt Lake Basins study unit began in 1997.

- Effects of stormwater runoff into streams from residential and commercial urban areas on water quality and aquatic biological communities;

- Effects of urban and agricultural land use in ground-water recharge areas on ground-water quality;

- Changes in aquatic biological communities as a result of changing land use and nonpoint pollution;

- Sediments eroded from stream banks as a result of fluctuating streamflow, modification of land cover, hydrologic changes that result from road development, and urbanization;

- High concentrations of nutrients from livestock grazing, feedlots, and natural factors that cause eutrophication, the process by which surface waters increase in biological productivity in response to nutrient enrichment; and

- Leachate from mine waste rock and possibly tailings in surface waters. 


\section{Description of the Great Salt Lake Basins study unit}

Most of the 14,500 square miles of the Great Salt Lake Basins study unit is in Utah but some areas in Idaho and Wyoming also are included. The study unit encompasses three major river systems that discharge into Great Salt Lake: the Bear, the Weber, and the Provo/Jordan. The Provo River and the Spanish Fork are large tributary drainages to Utah Lake, which is considered to be the headwaters of the Jordan River. The Jordan River flows northward from Utah Lake through the Salt Lake City metropolitan area before discharging into Great Salt Lake.

The study area includes the three largest cities in Utah (the Salt Lake City metropolitan area, Ogden, and Provo) and about 1.6 million people, or 85 percent of the population of the State. The population is expected to grow nearly 50 percent in the next 20 years, with most of the increase occurring in the study area.

The NAWQA study unit includes an area of diverse topography, geomorphology, natural vegetation, geology, and climate. Vegetation varies with altitude from barren mud flats and desert shrubs near the shore of Great Salt Lake at about 4,200 feet (ft), through scrub oak, aspen, and conifer forests in the Wasatch and Uinta Mountains, to barren areas above the timberline at 10,000 to $12,000 \mathrm{ft}$.

The headwaters of the three major river systems are in the western end of the Uinta Mountains. These streams flow through the wider valleys east of the Wasatch Range, emerge through the Range to the west, and discharge into Great Salt Lake.

The western side of the NAWQA study unit is in the Basin and Range Physiographic Province and the eastern side is in the Middle Rocky Mountains Physiographic Province. The stratigraphy is varied and includes formations from many geologic eras and periods and most types of rocks. Limestone and dolomitic rocks have

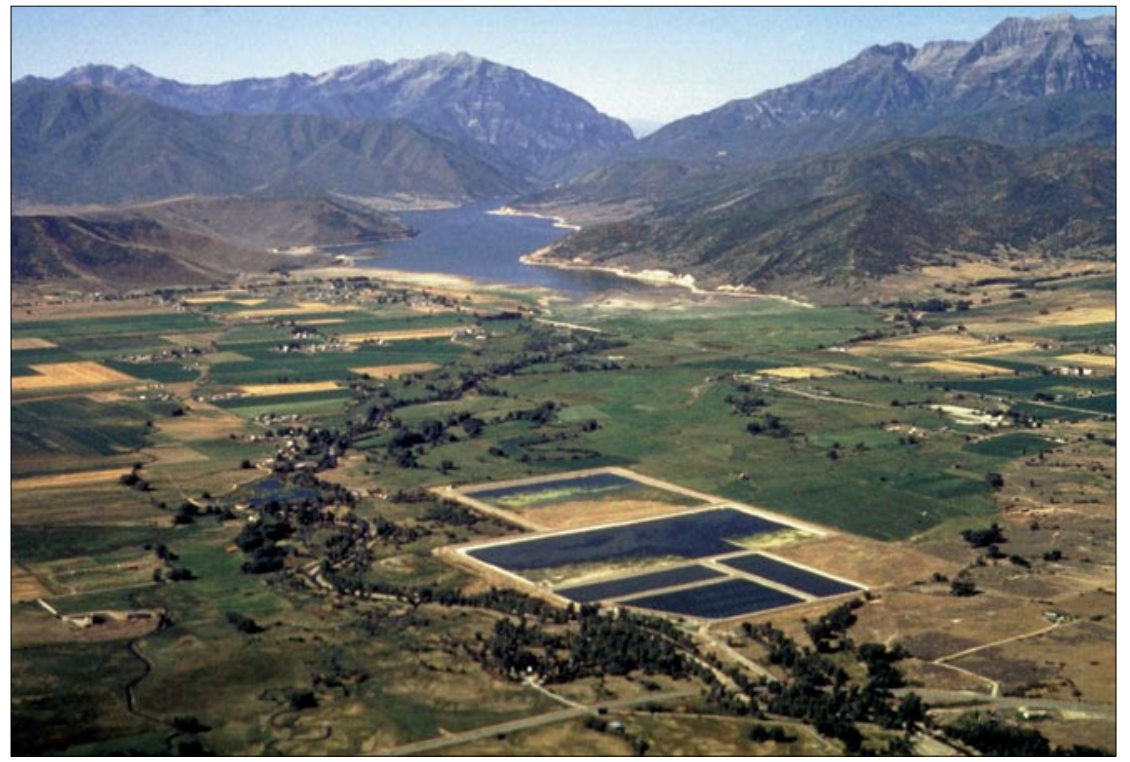

Water-treatment plant settling ponds and Deer Creek Reservoir. the greatest effect on the natural chemistry of ground and surface waters. Most of the ground-water supply in the study area is provided by aquifers in either the unconsolidated basin-fill deposits along the Wasatch Front, which runs along the mountain front on the western side of the Wasatch Range, or in unconsolidated valley-fill deposits along the major stream and structural valleys east of the Wasatch Range.

Annual precipitation ranges from less than 12 inches in the Salt Lake Valley to greater than 50 inches in the Wasatch Range 10 to 15 miles to the east. About 85 percent of the annual precipitation occurs as snow, which accumulates during October to April. Most of the runoff from the melting snowpack occurs during May to July.

Most of the urbanized area in the Great Salt Lake Basins NAWQA study unit is along the Wasatch Front near the mouths of the major rivers. In this area, runoff and drainage from urban and industrial land uses have the greatest effect on the quality of ground and surface waters in the Jordan River Basin. In the Bear River Basin, farm- ing and grazing on irrigated land are the uses that most affect water quality, even though they are not the predominant land use in the basin.

The estimated total withdrawal of water (off-stream) in the Great Salt Lake Basins NAWQA study unit was 2,797 million gallons per day (Mgal/d) in 1995. Of the total water withdrawals, $418 \mathrm{Mgal} / \mathrm{d}$ (15 percent) was from ground-water sources (wells and springs) and 2,379 Mgal/d (85 percent) was from surface-water sources. Hydroelectric water use (on-stream) was estimated to be 3,633 Mgal/d in 1995.

Bear Lake and several of the major reservoirs in the NAWQA study unit are managed for hydroelectric power, irrigation, public water supply, recreation, flood control, and fish propagation. The new Jordanelle Reservoir was developed as part of the Central Utah Project and is expected to provide about 100,000 acre-feet of water per year for municipal and industrial use to several counties along the Wasatch Front.

\section{NAWQA Sampling Design}

The NAWQA sampling design emphasizes a multidisciplinary approach by using physical, chemical, and biological tools to evaluate water-quality conditions. For surface waters such as streams and rivers, NAWQA focuses on a broad spectrum of water-quality parameters and sampling approaches to collect data on (1) hydrology, (2) inorganic water-quality constituents (major ions, trace elements, and nutrients), (3) physical water-quality characteristics (suspended sediment, $\mathrm{pH}$, specific conductance, and temperature), (4) trace

${ }^{1}$ Other is self-supplied domestic, self-supplied commercial, self-supplied industrial, and mining, fossilfuel, and livestock/animal specialties. 
elements and organic contaminants in water, bed material, and aquatic biota, and (5) biology and ecology (stream habitat, fish, benthic invertebrates, and algal communities).

Ground-water investigations in the NAWQA program focus primarily on (1) the spatial characterization of groundwater quality; (2) studies of the causal relations and processes that affect water quality; (3) movement of contaminants through the subsurface; and (4) changes in the quality of ground water over time.

Biological aspects of the NAWQA program are designed to evaluate interactions among the physical, chemical, and biological characteristics of streams and determine how biological and habitat characteristics differ among environmental settings. Ecological components of studies include the spatial distribution, abundance, and diversity of aquatic communities in relation to causative factors such as land use, contaminant sources, and instream habitat conditions. The study also assesses the concentrations and distributions of trace elements and hydrophobic organic contaminants in tissues of aquatic organisms.

\section{Surface-Water Sampling Plan}

NAWQA surface-water investigations consist of a network of sites designed to evaluate water-quality conditions throughout the basin. The basic fixed-site network consists of integrator sites (representing large sub-basins in the study area) and indicator sites (representing a predominant land-use or water-quality effect). Special types of indicator sites are reference sites that represent smaller basins minimally affected by land use.
Ten sites were selected as basic-fixed sites (four in the Bear River drainage, two in the Weber River drainage, and four in the Jordan River drainage). Monthly measurements at all 10 sites, beginning in October 1998, will include dissolved oxygen, $\mathrm{pH}$, alkalinity, specific conductance, temperature, suspended sediment, major ions, metals (selected sites), nutrients, and organic carbon.

Two areas have been selected for intensive studies of the effects of land use on the quality of surface water. Little Cottonwood Creek in Salt Lake County was selected as an urban study area and the Cub River in Cache Valley was selected as an agricultural study area.

\section{Ground-Water Sampling Plan}

Ground-water investigations in the Great Salt Lake Basins NAWQA unit consist of study-unit and land-use surveys. The study-unit survey samples water primarily from the deeper unconfined and confined basin-fill aquifers, which are the source of most of the water used for drinking and irrigation within the study unit. Because of the importance of these aquifers as a water source and because of susceptibility to contamination, water from 60 randomly distributed wells in recharge areas will be

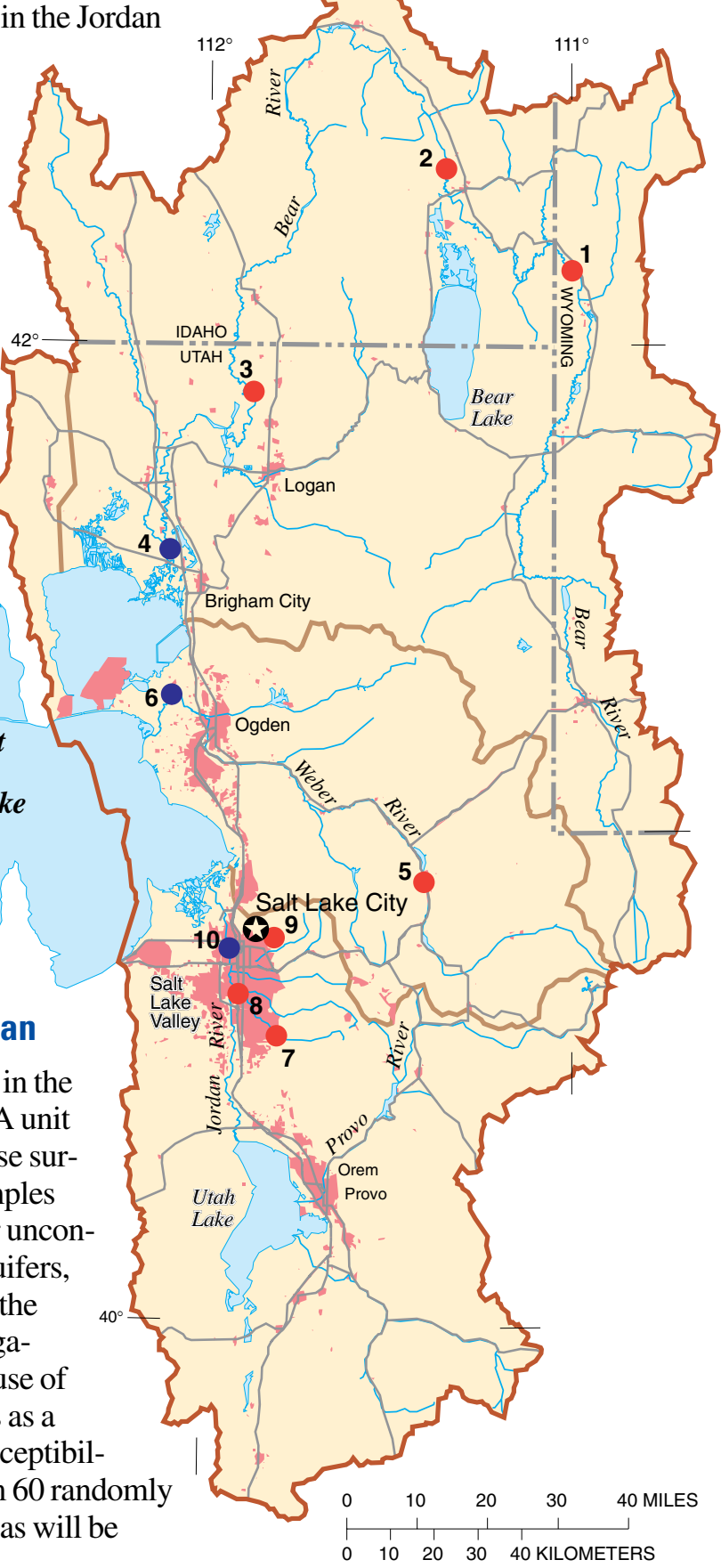

EXPLANATION

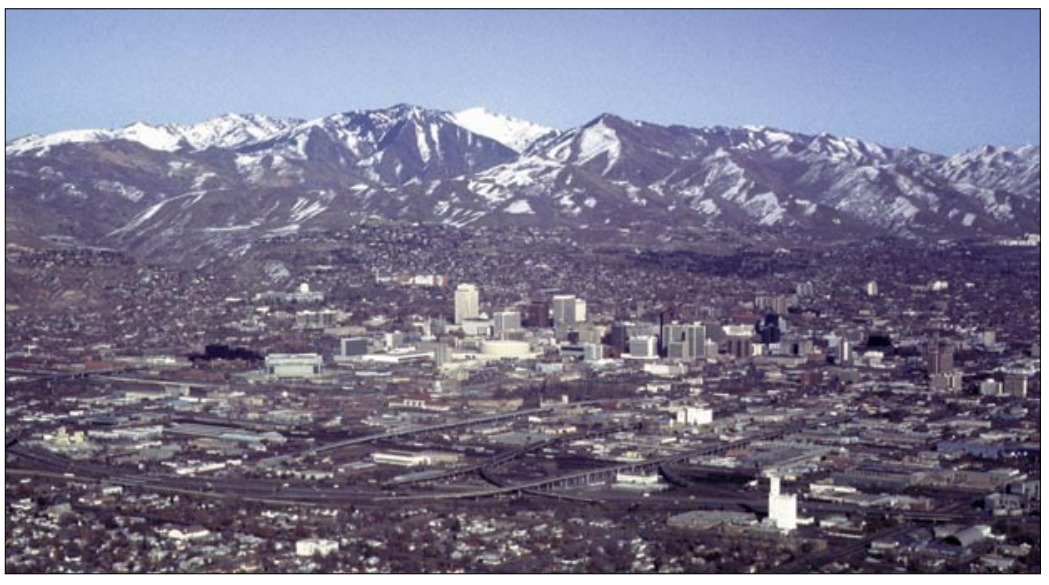

The Great Salt Lake Basins study unit includes Utah's three largest cities and 85 percent of the population of the State.

\section{Urban/industrial area \\ 4 Integrator site}

7 Indicator site

1 Bear River below Smith's Fork, near Cokeville, Wyoming

2 Bear River at Pescadero, Idaho

3 Cub River near Richmond, Utah

4 Bear River near Corinne, Utah

5 Weber River near Coalville, Utah

6 Weber River at Plain City, Utah

7 Little Cottonwood Creek at Crestwood Park, near Salt Lake City, Utah

8 Little Cottonwood Creek at Jordan River, near Salt Lake City, Utah

9 Red Butte Creek at Fort Douglas, near Salt Lake City, Utah

10 Jordan River at Salt Lake City, Utah 
sampled to better characterize these subunits.

Land-use surveys assess the quality of recently recharged ground water associated with predominant land-use activities. The shallow unconfined basin-fill aquifer in Salt Lake Valley has been selected for the urban land-use study, and the agricultural land-use study will focus on shallow ground water in areas with irrigated alfalfa. Water from wells installed or selected for these studies will be analyzed for major ions, nutrients, pesticides, volatile organic compounds, stable isotopes, organic carbon, radon-222, and tritium.

\section{Biological/Ecological Sampling Plan}

Eleven sites were selected for sampling of contaminants in sediments and tissues. These sites are generally in depositional environments that integrate either large areas of upstream drainage or represent localized and potentially significant sources of contaminants to aquatic systems.

The sites proposed for the ecological sampling represent a variety of habitat conditions, land use, and water-quality conditions.

\section{Communication and Coordination}

Communication and coordination among USGS personnel and other interested scientists and land- and water-management organizations are critical components of the NAWQA Program. Each of the study-unit investigations has a local liaison committee that consists of representatives from Federal, State, and local agencies, universities, and the private sector. Specific activities of each liaison committee include the exchange of information about waterquality issues of regional and local interest, identification and exchange of sources of data and information, assistance in the design and scope of project products, and review of project-planning documents and reports. The liaison committee for the Great Salt Lake Basins study unit was formed in 1994 and meets bi-annually.

\section{Selected References}

Gilliom, R.S., Alley, W.M., and Gurtz, M.E., 1995, Design of the National Water-Quality Assessment Program: Occurrence and distribution of waterquality conditions: U.S. Geological Survey Circular 1112, 33 p.

Toole, T.W., 1992, State of Utah water quality assessment for 1992: Utah Department of Environmental Quality, Division of Water Quality, Section 305(b) Report, Salt Lake City, Utah.

\section{Schedule of Study Activities}

The Great Salt Lake Basins study is one of several NAWQA studies that began in Federal fiscal year 1997 (October 1996). Study planning and analysis of existing data will be done during the first 2 years, which is consistent in all NAWQA studies. After the 2-year planning period, surfaceand ground-water and biological data are collected intensively for 3 years (termed the high-intensity phase). A low-intensity phase follows for 6 years, during which water quality is monitored at a selected number of sites and areas assessed during the high-intensity phase. This combination of high- and low-intensity-monitoring phases allows examination of trends in water quality over time.

During the planning period, existing data and results from previous studies are reviewed to understand the primary physi- cal, chemical, and biological factors that affect water quality in the study unit and to identify gaps in the current data. Descriptions of how land use and land cover, soils, geology, physiography, climate, and drainage characteristics may influence water quality are to be included in technical and nontechnical reports. Information obtained from reviews of previous studies, along with field checks of existing monitoring stations and candidate sampling sites, and field reconnaissance data, are used to design a sampling program for the study unit.

During the high-intensity phase, new chemical, physical, and biological data are collected for selected areas at local and regional scales to describe the quality of water throughout the study unit. Measurements are made to determine water chem-
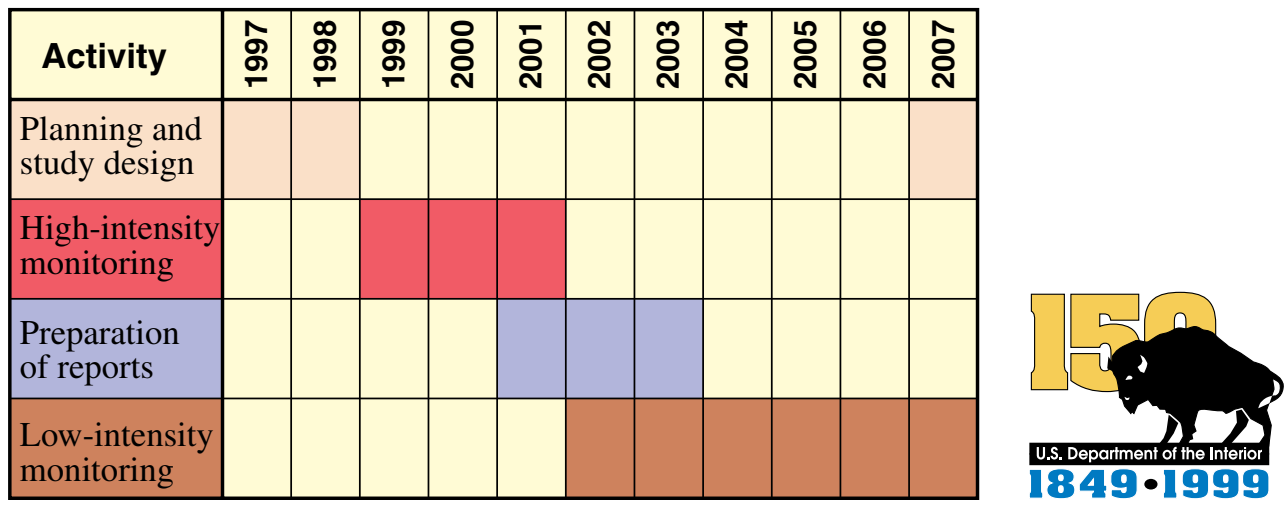

istry in streams and aquifers; the quantity of suspended sediment and the quality of bottom sediments in streams; the variety and number of fish, benthic invertebrates, and algae in streams; and the presence of contaminants in fish tissues. Individual streams and aquifers, chemical constituents, and biological species are selected for sampling to represent the important water resources and water-quality concerns in the study unit and in the Nation. A series of technical and nontechnical reports describing the results of high- and low-intensityphase data collection and analysis is planned.

Information on technical reports and hydrologic data related to the NAWQA program can be obtained from:

District Chief

Water Resources Division

U.S. Geological Survey

2329 Orton Circle

Salt Lake City, Utah 84119

Additional information about water resources in Utah is available on the world wide web at

http://ut.water.usgs.gov/ 